\title{
Future trends in environmental mercury concentrations: implications for prevention strategies
}

\author{
Elsie M Sunderland ${ }^{1 *}$ and Noelle E Selin²
}

\begin{abstract}
In their new paper, Bellanger and coauthors show substantial economic impacts to the EU from neurocognitive impairment associated with methylmercury ( $\mathrm{MeHg}$ ) exposures. The main source of $\mathrm{MeHg}$ exposure is seafood consumption, including many marine species harvested from the global oceans. Fish, birds and other wildlife are also susceptible to the impacts of MeHg and already exceed toxicological thresholds in vulnerable regions like the Arctic. Most future emissions scenarios project a growth or stabilization of anthropogenic mercury releases relative to present-day levels. At these emissions levels, inputs of mercury to ecosystems are expected to increase substantially in the future, in part due to growth in the legacy reservoirs of mercury in oceanic and terrestrial ecosystems. Seawater mercury concentration trajectories in areas such as the North Pacific Ocean that supply large quantities of marine fish to the global seafood market are projected to increase by more than $50 \%$ by 2050 . Fish mercury levels and subsequent human and biological exposures are likely to also increase because production of $\mathrm{MeHg}$ in ocean ecosystems is driven by the supply of available inorganic mercury, among other factors. Analyses that only consider changes in primary anthropogenic emissions are likely to underestimate the severity of future deposition and concentration increases associated with growth in mercury reservoirs in the land and ocean. We therefore recommend that future policy analyses consider the fully coupled interactions among short and long-lived reservoirs of mercury in the atmosphere, ocean, and terrestrial ecosystems. Aggressive anthropogenic emission reductions are needed to reduce MeHg exposures and associated health impacts on humans and wildlife and protect the integrity of one of the last wild-food sources globally. In the near-term, public health advice on safe fish consumption choices such as smaller species, younger fish, and harvests from relatively unpolluted ecosystems is needed to minimize exposure risks.
\end{abstract}

Keywords: Methylmercury, Health, Wildlife, Fish, Exposures, Costs, Emissions, Risk

\section{Background}

In their recent article, Bellanger et al. [1] quantified the monetary benefits from control of methylmercury $(\mathrm{MeHg})$ toxicity in European Union (EU) countries at between $€ 8,000$ and $€ 9,000$ million per year. The authors used population biomarker data to estimate that 1.5 to 2.0 million EU children are born each year exceeding exposure limits associated with long term IQ deficits. Given these severe effects and high costs to society, information on the benefits of

\footnotetext{
* Correspondence: elsie_sunderland@harvard.edu

'Department of Environmental Health, Harvard School of Public Health \& School of Engineering and Applied Sciences, Harvard University, Boston, Massachusetts, USA

Full list of author information is available at the end of the article
}

global emissions reduction is critically needed to support regulatory efforts aimed at reducing $\mathrm{MeHg}$ exposures.

Quantitative relationships linking changes in global anthropogenic mercury releases to human and biological exposures are still being developed. However, available information suggests aggressive global action to curb emissions is necessary to achieve declines in environmental concentrations. Here we briefly review biological exposures to mercury, environmental sources, and trends in concentrations that could impact human exposure. We conclude by discussing implications for prevention strategies.

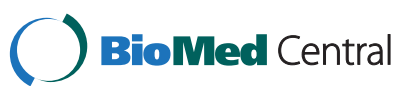

(c) 2013 Sunderland and Selin; licensee BioMed Central Ltd. This is an Open Access article distributed under the terms of the Creative Commons Attribution License (http://creativecommons.org/licenses/by/2.0), which permits unrestricted use, distribution, and reproduction in any medium, provided the original work is properly cited. 


\section{Pathways of exposure}

A dominant fraction of human exposure to $\mathrm{MeHg}$ is from consuming marine fish. For example, for the United States population an estimated $77 \%$ of $\mathrm{MeHg}$ exposure is from offshore marine fisheries [2,3]. Many vulnerable populations, particularly in northern regions, consume substantial quantities of marine mammals such as whale and seal that are also high in $\mathrm{MeHg}$ [4-6].

Given the importance of marine fish for human and biological exposures, much debate has arisen about the origin of mercury in marine ecosystems and the extent of perturbation by human influences. While some prior research suggested that $\mathrm{MeHg}$ in marine fish is naturally occurring (e.g., [7]), recent studies indicate that human impacts on ocean ecosystems are larger than previously thought $[8,9]$. Environmental concentrations of inorganic mercury drive the pool available for conversion to $\mathrm{MeHg}$ and subsequent bioaccumulation in aquatic food chains [10-12]. Many new data sets from ocean ecosystems suggest $\mathrm{MeHg}$ production is occurring in ocean seawater [13-19] and thus will be affected by changes in inorganic mercury concentrations in seawater.

Fish and other marine species are also susceptible to the impacts of MeHg. Depew et al. [20] showed reproductive and other sublethal effects occur in fish with tissue residues of MeHg below $0.2 \mu \mathrm{g} / \mathrm{g}$. By contrast, the tissue residue guideline established by the US EPA for safe consumption by humans is $0.3 \mu \mathrm{g} / \mathrm{g}$. Dietz et al. [21] showed that mercury concentrations already exceed toxicological thresholds for effects in many species including polar bears, and multiple species of seal, birds and fish from the Arctic. Common loons and songbirds in North America are also thought to be at risk from $\mathrm{MeHg}$ exposures $[22,23]$.

$\mathrm{MeHg}$ concentrations in biota have increased due to anthropogenic mercury in many regions. Museum feathers from an endangered seabird from the North Pacific (the black footed albatross) showed a sharp increase in $\mathrm{MeHg}$ concentrations since 1940 [24]. Dietz et al. [25] analyzed museum samples from marine-food webs in the Arctic and observed that mercury concentrations in began to rise around 1200 and showed a steep increase beginning in the mid- $19^{\text {th }}$ century. The authors attributed $>90 \%$ of this rise to anthropogenic mercury sources. Additional long term monitoring of biological datasets are needed to better quantify these trends and their drivers [26]. These data reinforce that anthropogenic mercury sources have had a substantial impact on human and biological exposures over time.

\section{Sources of environmental mercury}

Anthropogenic mercury emissions result both from intentional uses of mercury and from releases as a byproduct of other activities [27]. At present, coal combustion represents a substantial source of mercury to the environment, and about half of present-day emissions are from Asia [9]. Other sources include industrial processes such as cement production and chlor-alkali production, and uses of mercury in mining applications, including artisanal and small-scale gold mining [28].

Mercury emissions can be deposited on very different spatial scales depending on the chemical form in which they are emitted. Mercury in its elemental, gaseous form $\left(\mathrm{Hg}^{0}\right)$ can remain in the atmosphere for up to a year, transporting globally. Sources that release divalent $\left(\mathrm{Hg}^{\mathrm{II}}\right)$ and particulate $\left(\mathrm{Hg}^{\mathrm{P}}\right)$ mercury are shorter-lived, resulting in localized deposition. Previous work for the United States showed that while North American sources contribute only an average of $20 \%$ to domestic deposition, this fraction rises to $50 \%$ at locations downwind of major sources in the industrial Midwest [29].

Here, we show a similar analysis for Europe. Figure 1 shows the fraction of present day atmospheric mercury deposition in different regions of Europe from European anthropogenic sources, based on the GEOS-Chem global chemical transport model. European emissions contribute up to $60 \%$ of the deposition to ecosystems in industrial areas of Europe. In other areas, such as the Mediterranean, European emissions contribute $20 \%$ or less. This suggests that reducing deposition requires local, regional, and global policy actions [30].

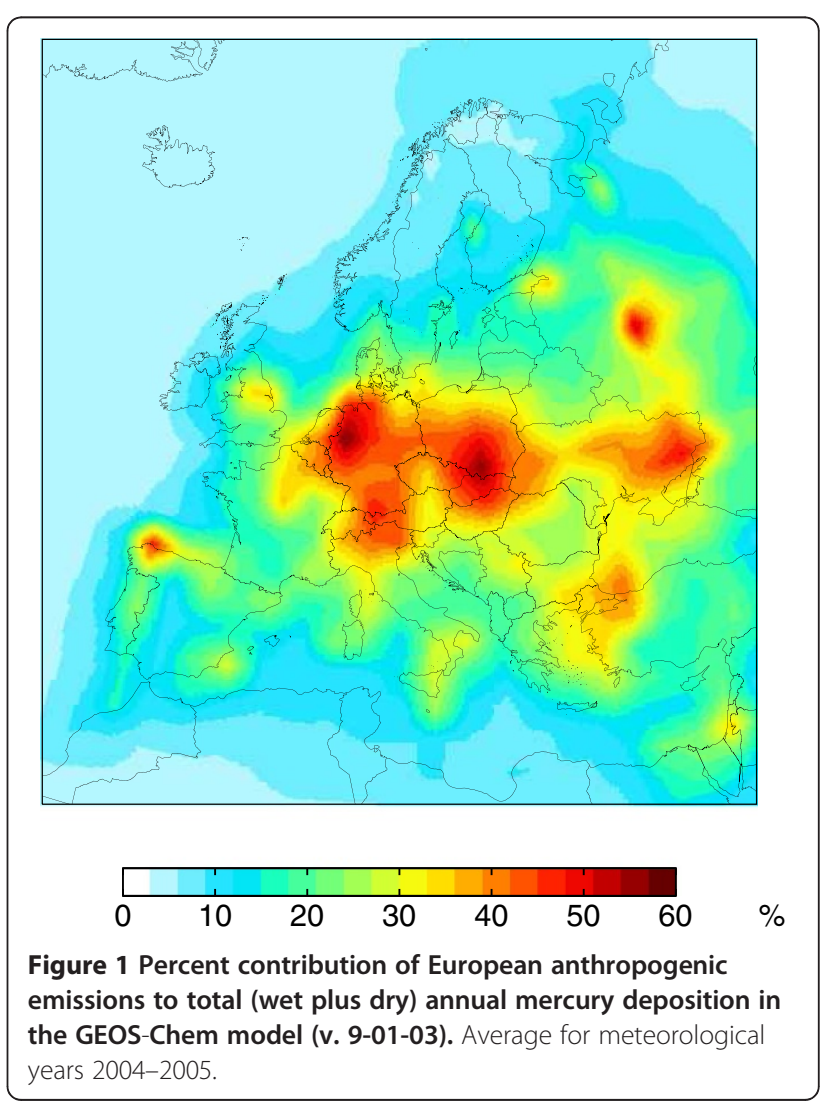


Mercury previously released from human activities continues to cycle through the atmosphere, ocean and terrestrial systems for hundreds to thousands of years [31]. This "legacy" mercury is emitted from land and ocean surfaces, and is a substantial component of present-day deposition to ecosystems. Prior work on the global biogeochemical cycle of mercury has estimated that present-day or "primary" anthropogenic emissions contribute about a third of the annual emissions to the atmosphere, with the remaining fractions from legacy and natural mercury sources [12,32-34]. Recent work by Amos et al. [8] suggests that the natural fraction of atmospheric mercury deposition is only $14 \%$ and will continue to be diminished over time if anthropogenic emissions continue on their present trajectory [8]. Results from Amos et al. [8] were derived by considering the full history of anthropogenic mercury emissions, including releases prior to the industrial period that are estimated to be $1 / 3$ of all time anthropogenic emissions [9].

\section{Future trends in mercury concentrations}

Anthropogenic mercury emissions are expected to rise or remain close to constant in the future, mainly because of the expansion of coal combustion projected in Asia [35]. Future mercury emissions projections to 2050 developed by Streets et al. [35] are shown in Figure 2a based on Intergovernmental Panel on Climate Change (IPCC) scenarios. The A1B scenario represents a growth storyline that is roughly equivalent to business-as-usual while the B scenarios represent local (B2) and global (B1) environmental sustainability initiatives. A2 represents large population growth but regionally oriented economic development. Emissions of mercury under B2 are roughly equivalent to present-day emissions levels (i.e., constant emissions from now to 2050). The B scenarios do not consider reductions achievable with mercury specific control technology. Thus, widespread application of mercury specific control technology globally could reduce future deposition to beyond the best-case (B1/B2) scenarios shown in Figure 2a.

Anthropogenic mercury emissions and subsequent deposition to ecosystems will continue to increase the legacy pool. This phenomenon is illustrated by Figure $2 b$, which shows legacy emissions make up a substantial component of 2050 deposition. The growth of legacy emissions reflects the fully-coupled biogeochemical cycle of mercury, where anthropogenic mercury is released from short and long lived reservoirs in terrestrial ecosystems and the oceans over timescales ranging from months to millennia. Results shown here are adapted from the biogeochemical modeling analysis of Amos et al. [8]. A zero anthropogenic emissions scenario bounds the extent of possible reductions in mercury emissions. Changes in deposition from the legacy pool have largely not been considered by the regulatory community to date.

Considering only changes in primary emissions (Figure 2a) may underestimate the extent of future increases in 2050 deposition (e.g., [36,37]) because such an analysis does not capture changes in the legacy mercury pool. One major benefit of near-term emissions reductions is a decline in the growth rate of the legacy pool that is sustained into the future (e.g., contrast the magnitude of legacy associated deposition in the A1B and B2 scenarios shown in Figure 2b). Decreases in atmospheric deposition on a global scale relative to present will only be possible in the future if emissions reductions
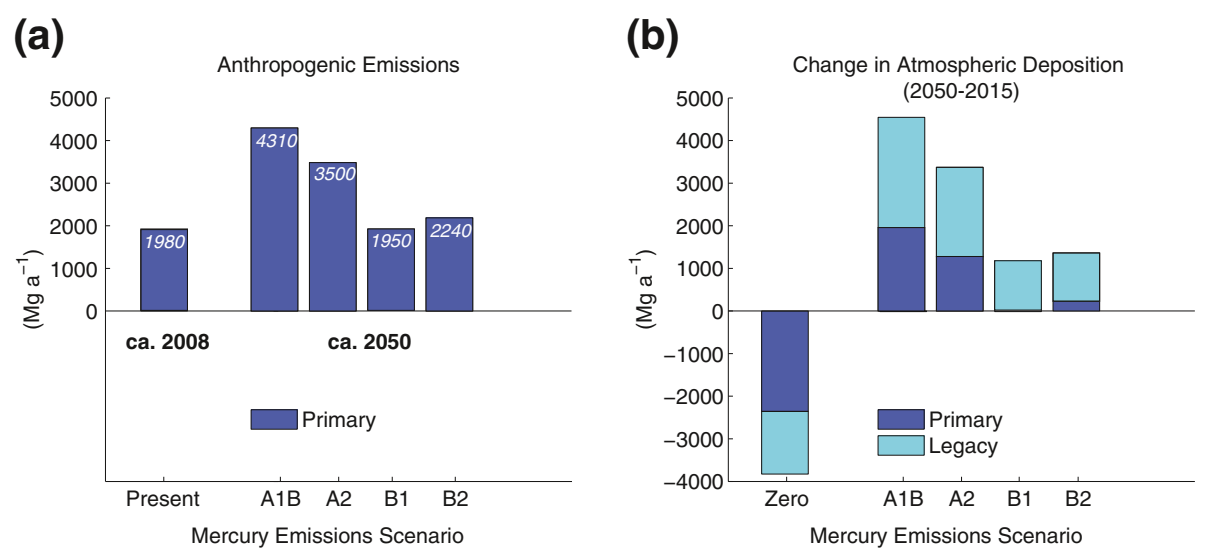

Figure 2 Projected primary anthropogenic mercury emissions in 2050 (panel a) and resulting changes in atmospheric deposition relative to 2015 (panel b). Year 2050 mercury emissions scenarios are from Streets et al. [34] based on IPCC projections and adjusted biomass burning for consistency with Streets et al. [9]. These scenarios are bounded by AlB representing a "business-as-usual" scenario with rapid economic growth, while B2 represents a best-case scenario without mercury specific controls (environmental sustainability initiatives and widespread implementation of control technology). The legacy component of deposition is driven by reemissions of previously deposited anthropogenic mercury from oceanic and terrestrial ecosystems. Panel (b) is based on the modeling analysis of Amos et al. [8]. 
are dramatic. Reaching such targets would likely require the application of mercury specific control technologies.

Sunderland et al. [17] used a combination of observations and modelling simulation to infer that at constant emissions levels seawater mercury concentrations in the North Pacific Ocean, a major seafood harvesting region, will rise by $50 \%$ in 2050 relative to 1995 levels. These results did not consider the additional burden imposed by the increasing fraction of mercury deposition from legacy emissions, as shown in Figure 2b. Thus, the trajectory of future $\mathrm{MeHg}$ concentrations in wild-fish stocks from the Pacific Ocean may be particularly dire in the absence of aggressive global cuts in anthropogenic mercury releases.

\section{Implications for prevention strategies}

Bellanger et al. [1] show that the annual economic costs associated with $\mathrm{MeHg}$ exposures in Europe are presently large. These exposures result from a combination of sources, including local and global contributions, as well as influence from present-day and legacy sources. Recent data and modeling studies suggest exposures may increase substantially in the future, particularly for commercial marine seafood consumers, assuming unchanged dietary habits and availability of fish.

From a policy perspective, designing interventions to effectively mitigate the harms posed by mercury requires actions that consider a variety of temporal and spatial scales. Potential interventions include both mitigation measures such as emissions reductions as well as adaptation strategies [30]. Implementation of mercury controls can lead to reductions in fish $\mathrm{MeHg}$ concentrations at local scales [10], but global-scale action is also necessary to address the mercury problem [38]. The ongoing negotiations under the United Nations Environment Programme for a global mercury treaty represent a step in that direction.

\section{Conclusions}

The long timescales of mercury cycling through the subsurface and deep ocean mean that any anthropogenic mercury releases persist and can affect biological exposures from timescales of centuries to millennia. As seafood is an important component of a healthy diet for many individuals, short-term solutions to elevated $\mathrm{MeHg}$ exposures will require changes in seafood consumption considering both risks and benefits [39]. While concentrations of $\mathrm{MeHg}$ in marine fish are likely to continue to exceed threshold levels, emissions reductions will have long-term benefits. Though full ecosystem recovery is only possible in the very distant future, policy action will benefit vulnerable species that accumulate $\mathrm{MeHg}$ and prevent further increases in $\mathrm{MeHg}$ in consumed species.

\section{Abbreviations}

EPA: Environmental Protection Agency; EU: European Union; $\mathrm{Hg}^{\mathrm{O}}$ : elemental mercury; $\mathrm{Hg}^{\prime \prime}$ : divalent inorganic mercury; $\mathrm{Hg}^{\mathrm{P}}$ : particulate mercury; MeHg: Methylmercury; IPCC: Intergovernmental Panel on Climate Change; IQ: Intelligence Quotient; US: United States.

\section{Competing interests}

The authors declare they have no competing interests.

\section{Authors' contributions}

EMS initiated the manuscript. EMS and NES both drafted the manuscript, read and approved the final version.

\section{Acknowledgments}

The authors acknowledge Helen Amos (Harvard) and Shaojie Song (MIT) for contributions to modeling analyses. NES and EMS acknowledge the U.S. National Science Foundation's Atmospheric Chemistry program (Grants1053648, 0961357)] and Chemical Oceanography Program (Grant 1130549). EMS also acknowledges financial support from the U.S. Environmental Protection Agency and the Harvard School of Public Health NIEHS Center for Environmental Health (P30 ES00002).

\section{Author details}

'Department of Environmental Health, Harvard School of Public Health \& School of Engineering and Applied Sciences, Harvard University, Boston, Massachusetts, USA. 'Engineering Systems Division \& Department of Earth, Atmospheric, and Planetary Sciences, Massachusetts Institute of Technology, Cambridge, Massachusetts, USA.

Received: 19 December 2012 Accepted: 19 December 2012 Published: 7 January 2013

\section{References}

1. Bellanger M, Pichery C, Aerts D, Berglund M, Castano A, Cejchanova M, Crettaz P, Davidson F, Esteban M, Exley K, et al: Economic benefits of methylmercury exposure control in Europe: Monetary value of neurotoxicity prevention. Environ Health 2013, in press.

2. Sunderland E, Corbitt ED, Cossa D, Evers D, Friedli HR, Krabbenhoft D, Levin L, Pirrone N, Rice G: Chapter 5: Impacts of Intercontinental Mercury Transport on Human and Ecological Health. In Hemispheric Tranport of Air Pollution, Part B, Mercury. Air Pollution Studies No. 18. Edited by Pirrone N, Keating T. Geneva: United Nations; 2010:145-179. ECE/EB.AIR/101.

3. Sunderland EM: Mercury exposure from domestic and imported estuarine and marine fish in the U.S. seafood market. Environ Health Perspect 2007 115:235-242.

4. Valera B, Dewailly E, Poirier P: Association between methylmercury and cardiovascular risk factors in a native population of Quebec (Canada): A retrospective evaluation. Environ Res 2012, in press. http://dx.doi.org/ 10.1016/j.envres.2012.08.002.

5. Weihe P, Hansen JC, Murata K, Debes F, Jorgensen PJ, Steuerwald U, White RF, Grandjean P: Neurobehavioral performance of Inuit children with increased pre-natal exposure to methylmercury. Int $J$ Circumpolar Health 2002, 61:41-49.

6. Grandjean P, Weihe P, White RF, Debes F, Araki S, Yokoyama K, Murata K, Sorensen N, Dahl R, Jorgensen PJ: Cognitive deficit in 7-year-old children with prenatal exposure to methylmercury. Neurotoxicol Teratol 1997, 19:417-428.

7. Kraepiel A, Keller K, Chin H, Malcolm E, Morel F: Sources and variations of mercury in tuna. Environ Sci Technol 2003, 37:5551-5558.

8. Amos HM, Jacob DJ, Streets DG, Sunderland EM: Legacy impacts of alltime anthropogenic emissions on the global mercury cycle. Global Biogeochem Cycles 2013, in review.

9. Streets DG, Devane MK, Lu Z, Bond TC, Sunderland EM, Jacob DJ: All-time releases of mercury to the atmosphere from human activities. Environ Sci Technol 2011, 45:10485-10491.

10. Harris R, Rudd J, Amyot M, Babiarz C, Beaty K, Blanchfield P, Bodaly R, Branfireun B, Gilmour C, Graydon J, et al: Whole ecosystem study shows rapid fish-mercury response to changes in mercury deposition. Proc Natl Acad Sci USA 2007, 104:16586-16591.

11. Knightes C, Sunderland E, Barber M, Johnston J, Ambrose RJ: Application of ecosystem scale fate and bioaccumulation models to predict fish 
mercury response times to changes in atmospheric deposition. Environ Toxicol Chem 2009, 28:881-893.

12. Mason RP, Choi AL, Fitzgerald WF, Hammerschmidt CR, Lamborg CH, Soerensen AL, Sunderland EM: Mercury biogeochemical cycling in the ocean and policy implications. Environ Res 2012, 119:101-117.

13. Cossa D, Averty B, Pirrone N: The origin of methylmercury in open Mediterranean waters. Limnol Oceanogr 2009, 54:837-844.

14. Cossa D, Heimburger L-E, Lannuzel D, Rintoul SR, Butler ECV, Bowie AR, Averty B, Watson RJ, Remenyi T: Mercury in the Southern Ocean. Geochim Cosmochim Acta 2011, 75:4037-4052.

15. Kirk JL, St Louis V, Hintelmann H, Lehnherr I, Else B, Poissant L: Methylated mercury species in marine waters of the Canadian High and Sub Arctic. Environ Sci Technol 2008, 42:8367-8373.

16. Mason RP, Fitzgerald W: Alkylmercury species in the equatorial Pacific. Nature 1990, 347:457-459.

17. Sunderland EM, Krabbenhoft DP, Moreau JW, Strode SA, Landing WM: Mercury sources, distribution, and bioavailability in the North Pacific Ocean: Insights from data and models. Global Biogeochem Cycles 2009, 23:GB2010.

18. Lehnerr I, St Louis VL, Hintelmann H, Kirk JL: Methylation of inorganic mercury in polar marine waters. Nat Geosci 2011, 4:298-302.

19. Wang F, Macdonald R, Armstrong D, Stern G: Total and methylated mercury in the Beaufort Sea: The role of local and recent organic matter remineralization. Environ Sci Technol 2012, 46:11821-11828.

20. Depew DC, Basu N, Burgess N, Campbell LM, Devlin EW, Drevnick PE, Hammerschmidt CR, Murphy CA, Sandheinrich MB, Weiner J: Toxicity of dietary methylmercury to fish: Derivation of ecologically meaningful threshold concentrations. Environ Toxicol Chem 2012, 31:1-12.

21. Dietz R, Sonne C, Basu N, Braune B, O'Hara T, Letcher RJ, Scheuhammer T, Andersen MPS, Andreasen C, Andriashek D, et al: What are the toxicological effects of mercury in Arctic biota? Sci Total Environ 2013, 443:775-790.

22. Evers DC, Savoy $\sqcup$, DeSorbo CR, Yates DE, Hanson W, Taylor KM, Siegel LS, Cooley JH, Bank MS, Major A, et al: Adverse effects from environmental mercury loads on breeding common loons. Ecotoxicology 2008, 17:69-81.

23. Jackson AK, Evers DC, Etterson MA, Condon AM, Folsom SB, Detweiler J, Schmerfeld J, Cristol JA: Mercury exposure affects the reproductive success of a free-living terrestrial songbird, the carolina wren (Thryothorus ludovicianus). Auk 2011, 128:759-769.

24. Vo ATE, Bank MS, Shine JP, Edwards SV: Temporal increase in organic mercury in an endangered pelagic seabird assessed by century-old museum specimens. Proc Natl Acad Sci USA 2011, 108:7466-7471.

25. Dietz R, Outridge PM, Hobson KA: Anthropogenic contributions to mercury levels in present-day Arctic animals-A review. Sci Total Environ 2009, 407:6120-6131.

26. Evers DC, Turnquist MA, Buck DG: Patterns of global seafood mercury concentrations and their relationship with human health, version 3, Biodiversity Research Institute. Gorham, Maine: Science Communications Series; 2012:12. 45. Note the publisher is Biodiversity Research Institute. The report is available here: http://www.zeromercury.org/index.php? option=com_phocadownload\&view=file\&id=172:bri-report-mercury-in-theglobal-environment-patterns-of-global-seafood-mercury-concentrations-andtheir-relationship-with-human-health\&ltemid $=70$.

27. Pacyna E, Pacyna J, Sundseth K, Munthe J, Kindbom K, Wilson S, Steenhuisen F, Maxson P: Global emission of mercury to the atmosphere from anthropogenic sources in 2005 and projections to 2020. Atmos Environ 2010, 44:2487-2499.

28. Sippl K, Selin H: Global policy for local livelihoods: Phasing out mercury in artisanal and small-scale gold mining. Environment 2012, 54:18-29.

29. Selin N, Jacob D: Seasonal and spatial patterns of mercury wet deposition in the United States: Constraints on the contribution from North American anthropogenic sources. Atmos Environ 2008, 42:5193-5204

30. Selin NE: Science and strategies to reduce mercury risks: a critical review. J Environ Monit 2011, 13:2389-2399.

31. Selin NE: Global biogeochemical cycling of mercury: A review. Annu Rev Environ Resour 2009, 34:43-63.

32. Selin NE, Sunderland EM, Knightes CD, Mason RP: Sources of Mercury Exposure for US Seafood Consumers: Implications for Policy. Environ Health Perspect 2010, 118:137-143.
33. Selin N, Jacob D, Yantosca R, Strode S, Jaegle L, Sunderland E: Global 3-D land-ocean-atmosphere model for mercury: Present-day versus preindustrial cycles and anthropogenic enrichment factors for deposition. Global Biogeochem Cycles 2008, 22:GB2011.

34. Sunderland EM, Mason R: Human impacts on open ocean mercury concentrations. Global Biogeochem Cycles 2007, 21:GB4022

35. Streets DG, Zhang Q: Projections of global mercury emissions in 2050. Environ Sci Technol 2009, 43:2983-2988.

36. Pirrone N, Keating T: Hemispheric Transport of Air Pollution, Part B: Mercury. In Air Pollution Studies No. 18. Geneva: Unted Nations; 2010. ECE/EB.AIR/101.

37. U.S. EPA: Regulatory Impact Analysis for the Final Mercury and Air Toxics Standard. NC: U.S. EPA, OAQPS, Research Triangle Park; 2011:510. EPA-452/ R-11-011.

38. Selin N, Selin H: Global politics of mercury pollution: The need for a multi-scale approach. Rev Eur Community Int Environ Law 2006, 15:258-269.

39. Mahaffey KR, Sunderland E, Chan HM, Choi AL, Grandjean P, Marien K, Oken E, Sakamoto M, Schoeny R, Weihe P, et al: Balancing the benefits of $n-3$ polyunsaturated fatty acids and the risks of methylmercury exposure from fish consumption. Nutr Rev 2011, 69:493-508.

doi:10.1186/1476-069X-12-2

Cite this article as: Sunderland and Selin: Future trends in environmental mercury concentrations: implications for prevention strategies.

Environmental Health 2013 12:2

\section{Submit your next manuscript to BioMed Central and take full advantage of:}

- Convenient online submission

- Thorough peer review

- No space constraints or color figure charges

- Immediate publication on acceptance

- Inclusion in PubMed, CAS, Scopus and Google Scholar

- Research which is freely available for redistribution 